\title{
A Study of Attitudes towards Teaching Profession of Commerce Stream Teachers of Kadi Taluka
}

\author{
Prof. Veenaben Patel $^{1 *}$, Trupti Upadhyay ${ }^{2}$
}

\section{ABSTRACT}

The best way to know the attitude of commerce teachers is to study professional attitude. According to this study professional attitude of commerce teacher towards their profession is average and it is different according to area and gender and difference found more than $60 \%$. Teacher's attitude directly on indirectly affects on students whether it is related to gender or area so, the purpose of this study is to know teachers attitude and then minimize the effect of teachers attitude on students it is also helpful for the professional betterment to teachers.

Keywords: Attitude, Commerce Stream Teachers, Kadi Taluka

Human life is full of many mysteries. Among the animal living on earth human being is an animal having specific abilities. Human being has filled his life with several colours. Human being has made life more beautiful and comfortable. Then why should the education of $21^{\text {st }}$ century remain aloof from such changes? Today, level of education is deteriorating day by day. Teachers do not do teaching work with interest. Corruption prevails in all fields of education. There may be many reasons behind it, and it is possible that some reasons may be with the teachers also, Therefore, a need originated to know their attitudes.

Teacher's attitudes directly or indirectly affect students. Therefore if a teacher's attitude is positive a teacher can contribute to the development of school, classroom and students.

\section{Importance of the study}

1. Present research focus on the attitude of teaching profession of commerce stream teachers.

2. Present research will be useful to know the attitude of the commerce stream teachers and its necessity.

\footnotetext{
${ }^{1}$ Dean \& Principal, Faculty of Education, Kadi Sarva Vishwavidyalaya, Gandhinagar, Gujarat, India

${ }^{2}$ Asst. Professor, Soorajba College of Education, Kadi, India

*Responding Author

(C) 2016, V Patel, T Upadhyay; licensee IJIP. This is an Open Access Research distributed under the terms of the Creative Commons Attribution License (http://creativecommons.org/licenses/by/2.0), which permits unrestricted use, distribution, and reproduction in any Medium, provided the original work is properly cited.
} 


\section{A Study of Attitudes towards Teaching Profession of Commerce Stream Teachers of Kadi Taluka}

3. Present research will be useful to know the problem regarding the attitude of commerce teachers.

4. Present research will be helpful to make necessary changes accordance with the teacher's profession.

5. Present research will be helpful to the teaching system and grow up the teaching.

\section{Objective}

1) To study the attitudes of commerce teachers towards teaching profession in terms of their gender.

2) To study the attitudes of commerce teachers towards teaching profession in terms of their area.

\section{Hypotheses}

Ho1 There will be no significant difference between the mean scores of attitudes of male teachers and female teachers of commerce faculty in Kadi Taluka towards the teaching profession.

Ho2 There will be no significant difference between mean scores of attitudes of teachers of rural area and urban areas of commerce faculty in Kadi Taluka towards teaching profession.

\section{Delimitation of the study}

The delimitations of the present study were following.

1. The present study was delimited only to Kadi taluka.

2. The present study was delimited only to Gujatati Medium schools of Kadi taluka.

3. Only commerce stream teachers considered as the high school teachers.

\section{Operational Definitions of key terms}

\section{Attitude}

Score obtained on self-constructed attitude scale is the attitude towards teaching profession in this study.

\section{Commerce stream}

After passing the $10^{\text {th }}$ standards from recognized board then select commerce stream.

\section{Kadi Taluka}

Kadi is taluka of Mehsana district in the Indian state of Gujarat. Kadi is known as "Cotton City".

\section{Research variable}

\begin{tabular}{|l|l|l|}
\hline \multicolumn{2}{|l|}{ Independent variable } & \multirow{2}{*}{ Dependent Variable } \\
\hline 1. Gender & 2. Area & \multirow{2}{*}{ Score of Attitude scale } \\
\cline { 1 - 2 } Male & Rural & \\
\hline Female & Urban & \\
\hline
\end{tabular}




\section{A Study of Attitudes towards Teaching Profession of Commerce Stream Teachers of Kadi Taluka}

\section{Research method}

This research aims at find out attitudes towards teaching profession. Therefore, the survey method was used in the research.

\section{Population}

The researcher has included all teachers of commerce faculty of Kadi Taluka in this study.

\section{Sample}

The sample includes 100 teachers of commerce faculty selected by stratified random sampling technique of Kadi Taluka.

\section{Tool}

In this research the investigator has used an attitude scale of find out attitudes towards teaching profession. The scale consists of 34 statements among which the statements numbering 3, 7, 8, 9, $12,13,17,21,25,26,27,30,32$ are negative statements. The remaining are positive statements. Reliability of the tool is 0.73 and content validity is finding out by expert suggestion.

\section{Data collection}

With prior permission of school principals the data were collected from the teachers with the help of attitude scale by giving them necessary instructions.

\section{DATA ANALYSIS METHOD}

The score on attitude scale were obtained from the teachers and a frequency distribution was prepared and mean and standard deviation were computed. Hypothesis tested by t-value. Then after levels of attitudes were determined of t-value was derived.

\begin{tabular}{|c|c|c|c|c|c|c|}
\hline \multicolumn{7}{|c|}{ Table:-1 } \\
\hline $\begin{array}{l}\text { Caste-wise } \\
\text { group }\end{array}$ & Strength & Mean & $\begin{array}{l}\text { Standard deviation } \\
\text { (S.D) }\end{array}$ & $\begin{array}{l}\text { Standard } \\
\text { (S.ED) }\end{array}$ & Error & t-value \\
\hline men & 48 & 65.29 & 7.49 & \multirow{2}{*}{\multicolumn{2}{|c|}{1.57}} & \multirow[t]{2}{*}{0.19} \\
\hline women & 52 & 65.59 & 8.23 & & & \\
\hline
\end{tabular}

\begin{tabular}{|l|l|l|l|l|l|}
\hline \multicolumn{2}{|c|}{ Table-2 } \\
\cline { 1 - 4 } grea-wise & strength & mean & $\begin{array}{l}\text { Standard } \\
\text { deviation (S.D) }\end{array}$ & SED & t-value \\
\hline Rural & 60 & 64.16 & 8.38 & 1.50 & 2.12 \\
\hline Urban & 40 & 67.37 & 6.63 & & \\
\hline
\end{tabular}




\section{INTERPRETATION}

\section{According to table -1}

1) The mean score and standard deviation of attitudes towards teaching profession of male teachers are 65.29 and 7.49 respectively.

2) The mean score and standard deviation of attitudes towards teaching profession of female teachers are 65.59 and 8.23 respectively.

3) The t-value of both groups is 0.19 which is lower than the tabulated value 1.96 at $\mathrm{df} 98$. Therefore it is hot found significant at 0.05 levels. Therefore this null-hypothesis is not rejected.

It means that there is no significant difference in attitudes towards teaching profession of female teachers and male teachers of commerce faculty in Kadi taluka. According to mean score attitude of female teachers towards their profession is found greater than male teachers.

\section{According to table - 2}

1) The mean scores and standard deviation of attitudes towards teaching profession of teachers of rural area 64.16 are and 8.38 respectively.

2) The mean scores and standard deviation of attitudes forwards teaching profession of teachers of urban area are 67.37 and 6.63 respectively.

3) The t-value of both groups is 2.12 which is greater than the tabulated value 1.96 at $\mathrm{df} 98$. Therefore the difference is not signification at 0.05 levels. Therefore the null hypothesis is rejected.

It means that there is significant difference in the attitudes towards teaching profession of teachers of rural area and urban area of commerce faculty in Kadi taluka. According to mean score attitude of urban teachers towards their profession is found greater than rural teachers.

\section{EDUCATIONAL IMPLICATIONS}

After a comprehensive study the above mentioned conclusion has been drawn out. On the basis of the conclusion emerged the following mentioned suggestions are to be made to the teaching professionals and society.

1) Positive attitude can be increase by organizing seminar, workshop, teachers training in rural area.

2) Attitude of teachers can be improved by institution for teachers’ job satisfaction.

3) Opportunities should be provide to the teachers from institution for professional growth.

\section{CONCLUSION}

Hence as per data analysis and testing of hypothesis the significant difference between male and female cannot found but area wise difference was found so it can be said that the attitude of different areas commerce teachers were differ rather than gender. As per present study researcher found that the attitude of commerce teacher towards their profession has been seen average more than $60 \%$. So, for the future study and reference we can use the data of area for future study as a research gape which can be study. 


\section{A Study of Attitudes towards Teaching Profession of Commerce Stream Teachers of Kadi Taluka}

\section{Acknowledgments}

The author appreciates all those who participated in the study and helped to facilitate the research process.

\section{Conflict of Interests}

The author declared no conflict of interests.

\section{REFERENCE}

Agarwal, S. (1988) Teacher Effectiveness of Female Teachers .Fifth survey of Educational Reserch.2, National Council of Educational Research and Training, New Delhi.

Best, John W.(1986). Research Education. New York: Prentice Hall Of India, Fifth Ed.

Garrett Henry E.(1981) statistics in psychology and education, Feffer and simons ltd, Bombay. Honby A.S.(1987). Oxford Advanced learner's Dictionary of current English, Bombay: Oxford University press.

How to cite this article: V Patel, T Upadhyay (2016), A Study of Attitudes towards Teaching Profession of Commerce Stream Teachers of Kadi Taluka, International Journal of Indian Psychology, Volume 3, Issue 4, No. 64, ISSN 2348-5396 (e), ISSN: 2349-3429 (p), DIP: 18.01.124/20160304, ISBN: 978-1-365-32519-9 